\section{ANALISIS PENERAPAN PAJAK PERTAMBAHAN NILAI PADA PT. SARANA ASPAL NUSANTARA}

\author{
Hadi Sutomo \\ Program Studi Akuntansi, Institut Bisnis dan Informatika Kesatuan, \\ Bogor Indonesia \\ Email:hadi.sutomo@gmail.com
}

Analisis
Penerapan Pajak
Pertambahan
Nilai pada PT
Sarana Aspal
Nusantara
$\mathbf{2 9 0}$

Submitted: MEI 2019

Accepted:

This resecarh was conducted with the aim to find out whether the application of Value Added Tax to the company is in accordance with applicable tax regulations. The research was carried out by analyzing the collection, calculation, payment and reporting of Value Added Tax. The data sampel used in this research is the VAT Report at PT. Sarana Aspal Nusantara for the periode of 2016 - 2017. The results showed that the company had implemented Value Added Tax in accordance with the applicable tax provisions. However there was still Correction to the noficication letter or monthly VAT report, while the occurrence of these corrections was due to several factors such as the replacement of tax invoice, cancelation of tax invoice, and other factors. Therefore for future research the analysis data related to the application of Value Added Tax must be expanded and not only limited to VAT Notification Letter but also to all matters that have relevance to Value Added Tax so that the research results are expected to be more optimal

Key Words : Value added tax, Equalization, Calculation, Payment and Tax Reporting

\section{PENDAHULUAN}

Self Assessment System merupakan salah satu sistem pemungutan pajak yang dianut oleh Negara Kesatuan Republik Indonesia. Dalam sistem ini negara memberikan kebabasan dan kepercayaan sepenuhnya kepada wajib pajak untuk mengelola kewajiban perpajakannya sendiri mulai dari menghitung hingga melaporkan jumlah pajak terutang. Sebagai salah satu sumber pendapatan negara yang utama, maka dalam proses pemungutan pajak perlu upaya dan kerja keras pemerintah agar dapat mendorong semua wajib pajak untuk membayar pajak dengan benar. Hal ini mengingat kebutuhan akan dana untuk membiayai pembangunan nasional dari tahun ke tahun terus mengalami peningkatan dengan jumlah yang tidak sedikit.

Pajak sebagai salah satu bentuk pungutan negera yang diatur oleh undang-undang, maka pemungutanny harus berdasarkan pada ketentuan peraturan perpajakan yang berlaku. PT. Sarana Aspal Nusantara merupakan salah perusahaan swasta di Samarinda provinsi Kalimantan Timur. Sebagai Pengusaha Kena Pajak maka PT. Sarana Aspal Nusantara berkewajiban membuat pencatatan atau pembukuan terutama yang berkaitan dengan transaksi penjualan maupun pembeliannya sehingga pelaksanaan kewajiban Pajak Pertambahan Nilai, diantara seperti penerbitan Faktur Pajak, pengkreditan Pajak Masukan, pembayaran pajak dan pelaporan SPT Masa PPN dapat dilakukan benar, dengan demikian dapat meminimalisasi terjadinya kesalahan yang dapat mengakibatkan dikenai sanksi

\footnotetext{
JIAKES

Jurnal Ilmiah Akuntansi Kesatuan Vol. 7 No 2, 2019 pg. $290-300$ IBI Kesatuan
ISSN $2337-7852$
} 
Analisis

Penerapan Pajak

Pertambahan

Nilai pada PT

Sarana Aspal

Nusantara perpajakan. Berdasarkan uraian diatas maka tujuan dari penelitian ini adalah untuk mengetahui bagaimana penerapan Pajak Pertambahan Nilai pada PT. Sarana Aspal Nusantara.

\section{TINJAUAN PUSTAKA}

\section{Pajak}

Pajak merupakan iuran wajib yang harus dibayarkan kepada negara oleh siapa saja yang wajib membayarnya sebagai salah satu bentuk partisipasi dalam pembangunan nasional. Untung Sukardji $(2015: 1)$ menyatakan bahwa pajak adalah iuran kepada negara (yang dapat dipaksakan) yang terutang oleh yang wajib membayarnya menurut peraturanperaturan, dengan tidak mendapat prestasi kembali yang langsung dapat ditunjuk dan yang gunanya adalah untuk membiayai pengeluaran-pengeluaran umum berhubung dengan tugas negara untuk menyelenggarakan pemerintahan. Dari definisi tersebut menunjukkan bahwa pajak memiliki peranan yang sangat penting dalam mendukung proses pembangunan nasional yang berkelanjutan, oleh karena itu sangat diperlukan upaya pemerintah sebagai regulator dan pengawas dalam rangka mengamankan penerimaan negara dari sektor pajak.

\section{Karkteristik dan Fungi Pajak}

Mardiasmo (2016:3-4) menjelaskan unsur-unsur yang menjadi karakteristik dari pajak yaitu iuran rakyat kepada negara yang harus dibayarkan dalam bentuk uang, dipungut berdasarkan undang-undang serta aturan pelaksanaanya, tanpa kontraprestasi dari negara yang secara langsung dapat ditunjuk, dan digunakan membiayai rumah tangga negara. Pajak memiliki dua fungsi yaitu a). fungsi anggaran (budgetair), pajak berfungsi sebagai salah satu sumber dana bagi pemerintah untuk membiayai pengeluaran-pengeluarannya dan b). fungsi mengatur (regulerend), pajak berfungsi sebagai alat untuk mengatur atau melaksanakan kebijakan pemerintah dalam bidang sosial dan ekonomi.

\section{Pajak Pertambahan Nilai}

Pajak Pertambahan Nilai adalah pajak atas konsumsi barang dan jasa di daerah Pabean yang dikenakan secara bertingkat disetiap jalur produksi dan distribusi (Darmansyah, 2013). Menurut Wardoyo dan Subiyakto (2017:150), PPN mempunyai sifatsifat yaitu :

a. Merupakan pajak tidak langsung, beban pajak dapat dialihkan kepada pihak lain, yaitu dari penjual dalihkan kepada pihak pembeli.

b. Pajak objektif, dikenakan atas objeknya tanpa terpengaruh unsur subjektifitas.

c. Bersifat multi stage levy namun non komulatif, dikenakan pada setiap rantai atau jalur produksi dan/atau distribusi.

d. Penghitungan PPN dengan metode pengurangan tidak langsung, pengkreditan PPN masukan terhadap PPN keluaran.

e. Pajak atas konsumsi di dalam negeri, yaitu dikenakan atas penyerahan/konsumsi/ pemanfaatan BKP (Barang Kena Pajak) dan/ atau JKP (Jasa Kena Pajak) di dalam negeri.

\section{Objek Pajak Pertambahan Nilai}

Menurut Wardoyo dan Subiyakto (2017 : 150-151) objek PPN berdasarkan Undang- Undang Nomor 42 Tahun 2009 Tentang Pajak Pertambahan Nilai dapat digolongkan menjadi tiga yaitu : a). Objek PPN Pasal 4 yang meliputi penyerahan BKP, 
JKP di dalam daerah pabean, pemanfaatan JKP, BKP Tidak Berwujud dari luar daerah pabean di dalam daerah pabean, Impor BKP, Ekspor BKP, JKP dan BKP tidak Berwujud oleh Pengusaha Kena Pajak, b) Objek PPN Pasal 16C yang meliputi kegiatan membangun sendiri yang dilakukan tidak dalam kegiatan usaha atau pekerjaan oleh orang pribadi atau badan yang hasilnya digunakan sendiri atau digunakan pihak lain, dan c). Objek PPN Pasal $16 \mathrm{D}$ yang meliputipPenyerahan BKP berupa aktiva yang menurut tujuan semula tidak untuk diperjual belikan oleh Pengusaha Kena Pajak (PKP0 kecuali atas penyerahan aktiva yang pajak masukannya tidak dapat dikreditkan sebagaimana dimaksud dalam pasal 9 ayat (8) huruf b dan huruf c Undang-Undang Nomor 42 Tahun 2009 Tentang Pajak Pertambahan Nilai.

\section{Subjek Pajak Pertambahan Nilai}

Subjek PPN adalah Pengusaha Kena Pajak yaitu orang/badan yang melakukan penyerahan BKP dan/atau JKP, Pemungut PPN sebagai subjek pajang pengganti (Bendaharawan Pemerintah Pusat atau Daerah, BUMN, KPPN, dan Kontraktor Kontrak Kerja Sama Pengusahaan Minyak dan Gas Bumi serta Sumber Daya Panas Bumi), dan Importir yaitu pihak yang melakukan kegiatan memasukan barang dari luar daerah pabean ke dalam daerah pabean (Wardoyo dan Subiaykto, 2017 : 157-158).

\section{Saat dan Tempat Terutangnya Pajak Pertambahan Nilai}

Mardiasmo (2016: 348) menyatakan bahwa saat terutangnya PPN adalah pada saat penyerahan BKP atau JKP, impor BKP, pemanfaatan BKP Tidak Berwujud dari luar daerah pabean di dalam daerah pabean, pemanfaatan JKP dari luar daerah pabean, Ekspor BKP Berwujud, Ekspor BKP Tidak Berwujud, Ekspor JKP, dan Pembayaran, pembayaran yang diterima sebelum penyerahan BKP atau sebelum penyerahan JKP atau dalam hal pembayaran dilakukan sebelum dimulainya pemanfaatan BKP Tidak Berwujud atau JKP dari luar daerah pabean. Sedangkan tempat terutangnya PPN ditentukan sebagai berikut :

a. Untuk Penyerahan BKP/JKP, terutangnya pajak di tempat tinggal/ tempat kedudukan/ tempat kegiatan usaha/ tempat lain dan apabila PKP terutang pajak lebih dari 1 (satu) tempat kegiatan usaha, PKP tersebut dalam pemenuhan kewajiban perpajakannya dapat menyampaikan pemberitahuan secara tertulis kepada Direktur Jenderal Pajak untuk memilih 1 (satu) tempat atau lebih sebagai tempat terutangnya pajak.

b. Dalam hal Impor, terutangnya pajak terjadi ditempat BKP dimasukan dan dipungut melalui Direktorat Jenderal Bea dan Cukai.

c. Orang pribadi atau badan yang memanfaatkan BKP Tidak Berwujud dan/atau JKP dari luar daerah pabean di dalam daerah pabean terutang pajak di tempat tinggal atau tempat kedudukan dan/atau tempat kegiatan usaha.

d. Untuk kegiatan membangun sendiri oleh PKP yang dilakukan tidak dalam lingkungan perusahaan atau pekerjaannya atau oleh bukan PKP, ditempat bangunan tersebut didirikan.

\section{Tarif Dan Cara Menghitung Pajak Pertambahan Nilai}

Berdasarkan ketentuan Pasal 7 Undang-Undang Nomor 42 Tahun 2009 Tentang Pajak Pertambahan Nilai, tarif PPN ditetapkan sebesar 10\% dan 0\%. Tarif 0\% hanya diterapkan atas ekspor BKP Berwujud, ekspor BKP Tidak Berwujud dan Ekspor JKP. Namun berdasarkan ketentuan Undang-Undang tersebut, tarif PPN dapat diubah menjadi paling rendah $5 \%$ dan paling tinggi $15 \%$ yang perubahan tarifnya diatur dengan Peraturan Pemerintah. Cara menghitung PPN adalah dengan cara mengalikan tarif PPN dengan Dasar Pengenaan Pajak yang meliputi Harga Jual, Penggantian, Nilai Impor, Nilai Ekspor, atau
Penerapan Pajak

Pertambahan Nilai pada $P T$ Sarana Aspal

Nusantara

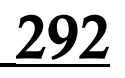

Analisis
Nusantara 
nilai Lain yang diatur dengan atau beradasarkan Peraturan Menteri Keuangan. Atas secara dapat dirumuskan sebagai berikut :

Analisis

Penerapan Pajak

Pertambahan

Nilai pada PT

Sarana Aspal

Nusantara

293
PPN = Dasar Pengenaan Pajak x Tarif Pajak

\section{Mekanisme Pengkreditan Pajak Masukan}

Pajak Masukan merupakan pajak yang bayarkan oleh PKP atas pembelian BKP, penerimaan JKP, impor BKP, pemanfaat BKP Tidak Berwujud dari luar daerah pabean atau pihak yang memanfaatkan JKP dari luar daerah pabean, sedangkan Pajak Keluaran merupakan pajak yang dipungut oleh PKP atau penjualan atau penyerahan BKP dan/atau JKP kepada pembeli atau pelanggannya. Pajak Masukan tersebut dapat dikreditkan dengan Pajak Keluaran yang dipungutnya dalam masa pajak yang sama. Pajak Masukan yang dapat dikreditkan, tetapi belum dikreditkan dengan Pajak Keluaran pada masa pajak yang sama, dapat dikreditkan pada masa pajak berikutnya paling lama tiga bulan setelah berakhirnya masa pajak yang bersangkutan sepanjang belum dibebankan sebagai biaya dan belum dilakukan pemeriksaan.

Apabila dalam satu masa pajak, jumlah Pajak Masukan lebih besar dari pada jumlah Pajak Keluaran maka selisihnya merupakan kelebihan pajak yang dapat dimintakan kembali (restitusi) atau dikompensasikan ke masa pajak berikutnya. Sedangkan pada satu masa pajak jumlah Pajak Keluaran lebih besar dari pada jumlah Pajak Masukan maka selisihnya merupakan kekurangan pajak yang harus disetorkan ke Kas Negara paling lama akhir bulan berikutnya setelah masa pajak berkahir dan sebelum SPT Masa PPN disampikan/dilaporkan.

Lalujan (2013), telah melakukan penelitian tentang Pajak Pertambahan Nilai pada PT. Agung Utara Sakti Manado dimana hasil penelitiannya mengemukakan bahwa jumlah pendapatan dalam laporan keuangan periode tahun 2009-2011 sebanding dengan jumlah PPN Keluaran yang tertera dalam SPT Masa PPN periode tahun 2009 - 2011 dan tidak terdapat pembetulan SPT Masa PPN, hal ini menunjukkan bahwa perusahaan telah melakukan perhitungan PPN dengan benar dan sesuai Undang-Undang No. 42 Tahun 2009, selain itu tidak ditemukannya adanya sanksi administrasi berupa denda sehingga hal ini menunjukkan bahwa tidak ada keterlambatan dalam hal pelaporan SPT Masa PPN.

Darmansyah (2013), dalam penelitiannya yang berjudul Analisis Penerapan SPT Masa PPN dan Hubungannya Terhadap Laporan Keuangan Pada PT. Duta Firza, hasil penelitian menunjukkan bahwa selama periode tahun 2010 perusahaan telah melaporkan SPT Masa PPN dengan tepat waktu meskipun terdapat pembetulan pada masa pajak Februari, April, Juni, Juli, Agustus, September, Oktober dan November namun pembetulan tersebut bukan merupakan keterlambatan pelaporan sehingga tidak menimbulkan sanksi administrasi denda. Selain itu jumlah saldo kurang bayar pada SPT PPN Masa Desember 2010 sesuai dengan jumlah hutang pajak yang tercatat dalam Neraca perusahaan, hal ini menunjukan bahwa pencatatan atas PPN telah dilakukan dengan benar dan perhitungan PPN sudah sesuai dengan ketentuan perpajakan yang mengatur tentang PPN yaitu UndangUndang No. 42 Tahun 2009.

Januri (2017), dalam penelitiannya yang berjudul Analisis Penerapan Akuntansi Pajak Pertambahan Nilai Pada PT. Perkebunan Nusantara IV Medan, hasil penelitian mengemukakan bahwa pada periode tahun 2015 terdapat selisih pengakuan penjualan antara SPT Masa PPN dengan laporan laba rugi perusahaan yang disebabkan karena adanya perbedaan saat penyerahan barang dengan saat pembuatan faktur dan kebijakan pemberian 
potongan penjualan, namun demikian perhitungan PPN Masukan dan PPN Keluaran telah sesuai dengan ketentuan peraturan perpajakan yang belaku dan SPT Masa PPN telah dilaporkan dengan tepat waktu.

\section{METODE PENELITIAN}

Analisis

Data yang digunakan dalam penelitian ini berupa data-data laporan keuangan dan data-data Surat Pemberitahun (SPT) Pajak Pertamban Nilai, sehingga termasuk dalam kategori data sekunder. Darmayanti (2012) menyatakan bahwa data sekunder adalah data yang diperoleh dalam bentuk yang sudah terjadi publikasi, diantaranya seperti sejarah perusahaan, struktur organisasi, data perhitungan pajak dan laporan keuangan. Sumber data dalam penelitian ini diperoleh dari PT. Sarana Aspal Nusantara yaitu berupa data laporan keuangan dan SPT Masa PPN periode tahun 2016 - 2017. Teknik pengumpulan data yang digunakan dalam penelitian ini adalah penelitian kepustakaan (library research), sedangkan metode analisis yang digunakan dalam penelitian ini adalah metode analisis deskriptif.

\section{HASIL PENELITIAN DAN PEMBAHASAN}

PT. Sarana Aspal Nusantara adalah sebuah perusahaan swasta yang bekedudukan di Samarinda, Provinsi Kalimantan Timur. Sejak awal didirikan pada tahun 2001 perusahaan menjalankan usaha perdagangan distribusi aspal dan saat ini perusahaan terdaftar sebagai Agen Aspal PT. Pertamina (Persero). Perusahaan telah dikukuhkan sebagai Pengusaha Kena Pajak dengan Nomor PKP : 02.054.477.1.725.000. Sebagai Pengusaha Kena Pajak, perusahaan telah melaksanakan hak dan kewajiban perpajakan Pajak Pertambahan Nilai yang meliputi memungut PPN, menerbitkan faktur pajak, mengreditkan Pajak Masukan dan mengkompensasikan PPN lebih bayar melalui mekanisme pengkreditan Pajak Masukan, membayar PPN kurang bayar ke kas negara dan membuat laporan SPT Masa PPN sesuai dengan ketentuan peraturan perpajakan yang berlaku.

Tabel 1

Rekapitulasi Perhitungan Pajak Keluaran Periode Tahun 2016 - 2017

(Dalam Rupiah)

\begin{tabular}{|l|c|c|c|c|c|c|}
\hline \multirow{2}{*}{ Masa } & \multicolumn{3}{|c|}{ Tahun 2016 } & \multicolumn{3}{c|}{ Tahun 2017 } \\
\cline { 2 - 7 } & DPP & Tarif & PPN & DPP & Tarif & PPN \\
\hline Januari & 174.000 .000 & $10 \%$ & 17.400 .000 & 3.855 .909 .092 & $10 \%$ & 385.590 .908 \\
\hline Februari & 149.090 .910 & $10 \%$ & 14.909 .090 & 1.410 .000 .003 & $10 \%$ & 140.999 .997 \\
\hline Maret & 1.641 .818 .183 & $10 \%$ & 164.181 .817 & 2.826 .818 .181 & $10 \%$ & 282.681 .819 \\
\hline April & 3.175 .909 .090 & $10 \%$ & 317.590 .910 & 4.624 .999 .999 & $10 \%$ & 462.500 .001 \\
\hline Mei & 15.133 .636 .365 & $10 \%$ & 1.513 .363 .635 & 5.714 .090 .915 & $10 \%$ & 571.409 .085 \\
\hline Juni & 14.687 .164 .557 & $10 \%$ & 1.468 .716 .443 & 7.656 .363 .644 & $10 \%$ & 765.636 .356 \\
\hline Juli & 7.206 .590 .909 & $10 \%$ & 720.659 .091 & 10.419 .090 .924 & $10 \%$ & 1.041 .909 .076 \\
\hline Agustus & 12.363 .909 .091 & $10 \%$ & 1.236 .390 .909 & 11.206 .500 .022 & $10 \%$ & 1.120 .649 .978 \\
\hline September & 9.172 .909 .099 & $10 \%$ & 917.290 .901 & 9.684 .363 .637 & $10 \%$ & 968.436 .363 \\
\hline Oktober & 11.983 .454 .545 & $10 \%$ & 1.198 .345 .455 & 7.192 .954 .551 & $10 \%$ & 719.295 .449 \\
\hline November & 14.385 .288 .637 & $10 \%$ & 1.438 .528 .863 & 6.061 .022 .731 & $10 \%$ & 606.102 .269 \\
\hline Desember & 9.123 .181 .829 & $10 \%$ & 912.318 .171 & 3.061 .545 .460 & $10 \%$ & 306.154 .540 \\
\hline \multicolumn{1}{|c|}{ Total } & $\mathbf{9 9 . 1 9 6 . 9 5 3 . 2 1 5}$ & & $\mathbf{9 . 9 1 9 . 6 9 5 . 2 8 5}$ & $\mathbf{7 3 . 7 1 3 . 6 5 9 . 1 5 9}$ & & $\mathbf{7 . 3 7 1 . 3 6 5 . 8 4 1}$ \\
\hline
\end{tabular}

Sumber : Data diolah 
Analisis

Penerapan Pajak

Pertambahan

Nilai pada PT

Sarana Aspal

Nusantara

$\underline{295}$
Berdasarkan Tabel 1 diatas menunjukkan bahwa selama periode tahun 2016 perusahaan telah melakukan transaksi penjualan senilai Rp 99.196.953.215 dengan PPN yang dipungut senilai Rp 9.919.695.285. Sedamgkan selama periode tahun 2017 perusahaan telah melakukan transaksi penjualan senilai Rp 73.713.659.159 dengan PPN yang dipungut senilai $\mathrm{Rp}$ 7.371.365.841. Dengan demikian perusahaan telah melakukan pemungutan pajak dengan tarif sesuai dengan ketentuan Pasal 7 Undang-Undang Nomor 42 Tahun 2009 Tentang Pajak Pertambahan Nilai yaitu sebesar 10\%, meskipun dari data Tabel 1 tesebut menunjukan adanya sedikit perbedaan angka pada nilai PPN yang dihasilkan dari perkalian antara DPP dengan tarif PPN 10\%, namun perbedaan tersebut tidak berpengaruh secara signifikan dalam menentukan besarnya pemungutan PPN sebab perbedaan tersebut terjadi karena adanya pembulatan angka desimal pada saat pembuatan e-faktur.

Secara akuntansi, setiap transaksi penjualan akan dicatat sebagai penjualan atau pendapatan dan atas penerimaan pembayaran dimuka akan dicatat sebagai hutang lancar (uang muka penjualan), sedangkan secara perpajakan setiap penyerahan barang dan/atau jasa dan penerimaan pembayaran dimuka terutang PPN sehingga hal ini akan terdapat perbedaan antara akuntansi dan pajak. Oleh karena itu pada setiap masa pajak perlu dilakukan equalisasi antara penjualan dengan DPP PPN, hal ini untuk mengetahui penyebab apabila terdapat perbedaan antara penjulan sesuai laporan laba/(rugi) dengan DPP PPN pada SPT Masa PPN.

Tabel 2

Equalisasi Penjualan vs DPP PPN Periode Tahun 2016

(Dalam Rupiah)

\begin{tabular}{|c|c|c|c|c|c|c|}
\hline \multirow{2}{*}{ Masa } & \multirow{2}{*}{$\begin{array}{c}\text { Penjualan } \\
\text { Lap. Laba/(Rugi) }\end{array}$} & \multirow{2}{*}{$\begin{array}{c}\text { DPP } \\
\text { SPT PPN }\end{array}$} & \multirow{2}{*}{$\begin{array}{c}\text { Selisih } \\
\text { Awal }\end{array}$} & \multicolumn{2}{|c|}{ Penjelasan Selisih } & \multirow{2}{*}{$\begin{array}{l}\text { Selisih } \\
\text { Akhir }\end{array}$} \\
\hline & & & & Penerimaan UM & Realisasi UM & \\
\hline Januari & 174.000 .000 & 174.000 .000 & 0 & 0 & 0 & 0 \\
\hline Februari & 149.090 .910 & 149.090 .910 & 0 & 0 & 0 & 0 \\
\hline Maret & 1.641 .818 .183 & 1.641 .818 .183 & 0 & 0 & 0 & 0 \\
\hline April & 3.175 .909 .090 & 3.175 .909 .090 & 0 & 0 & 0 & 0 \\
\hline Mei & 15.033 .409 .093 & 15.133 .636 .365 & -100.227 .272 & 200.454 .545 & -100.227 .273 & 0 \\
\hline Juni & 13.878 .300 .921 & 14.687 .164 .557 & -808.863 .636 & 909.090 .909 & -100.227 .273 & 0 \\
\hline Juli & 7.206.590.909 & 7.206.590.909 & 0 & 0 & 0 & 0 \\
\hline Agustus & 12.418 .454 .546 & 12.363 .909 .091 & 54.545 .455 & 0 & -54.545 .455 & 0 \\
\hline September & 9.172 .909 .099 & 9.172 .909 .099 & 0 & 0 & 0 & 0 \\
\hline Oktober & 12.365 .272 .729 & 11.983 .454 .545 & 381.818 .184 & 0 & -381.818 .184 & 0 \\
\hline November & 14.858 .015 .912 & 14.385.288.637 & 472.727 .275 & 0 & -472.727 .275 & 0 \\
\hline Desember & 9.123 .181 .829 & 9.123.181.829 & 0 & 0 & 0 & 0 \\
\hline Total & 99.196.953.221 & 99.196.953.215 & 6 & 1.109 .545 .454 & -1.109 .545 .460 & 0 \\
\hline
\end{tabular}

Sumber : Data diolah

Berdasarkan pada Tabel 2 tersebut diatas dapat diketahui bahwa pada Masa Pajak Mei, Juni, Agustus, Oktober, dan November dalam periode tahun 2016 terdapat selisih antara jumlah penjualan sesuai laporan laba/(rugi) dengan jumlah DPP PPN sesuai SPT Masa PPN, begitu pula dengan yang terjadi pada Masa Pajak Januari, Maret, April, Juni, Juli, Agustus, September, Oktober dan November periode tahun 2017 (lihat Tabel 3), terdapat selisih antara jumlah penjualan sesuai laporan laba/(rugi) dengan jumlah DPP PPN sesuai SPT Masa PPN. Mardiasmo (2016: 348), menyatakan bahwa saat terutangnya PPN diantarnya adalah pada saat pembayaran yang diterima sebelum penyerahan BKP atau sebelum penyerahan JKP. Sehingga dalam hal ini perusahaan wajib memungut PPN dan menerbitkan Faktur Pajak pada saat menerima uang muka penjualan, meskipun secara akuntansi uang muka penjualan tersebut belum dapat diakui sebagai penjualan karena 
secara akuntansi uang muka penjualan tersebut akan di adjustment ke penjualan apabila uang muka tersebut telah direalisasikan sebagai penjualan yaitu pada saat barang dan/atau jasa diserahkan kepada pelanggan. Pada saat direalisasi uang muka penjualan sebagai penjualan maka tidak perlu lagi membuat Faktur Pajak sebab Faktur Pajak telah dibuat pada saat diterimanya uang muka tersebut.

Tabel 3

Equalisasi Penjualan vs DPP PPN Periode Tahun 2017

(Dalam Rupiah)

\begin{tabular}{|c|c|c|c|c|c|c|}
\hline \multirow{2}{*}{ Masa } & \multirow{2}{*}{$\begin{array}{c}\text { Penjualan } \\
\text { Lap. } \text { Laba/(Rugi) }\end{array}$} & \multirow{2}{*}{$\begin{array}{c}\text { DPP } \\
\text { SPT PPN }\end{array}$} & \multirow{2}{*}{$\begin{array}{c}\text { Selisih } \\
\text { Awal }\end{array}$} & \multicolumn{2}{|c|}{ Penjelasan Selisih } & \multirow{2}{*}{$\begin{array}{l}\text { Selisih } \\
\text { Akhir }\end{array}$} \\
\hline & & & & Penerimaan UM & Realisasi UM & \\
\hline Januari & 1.151 .363 .643 & 3.855 .909 .092 & -2.704 .545 .449 & 2.704 .545 .455 & 0 & 6 \\
\hline Februari & 1.409 .999 .997 & 1.410 .000 .003 & -6 & 0 & 0 & -6 \\
\hline Maret & 2.714 .999 .997 & 2.826 .818 .181 & -111.818 .184 & 190.909 .091 & -79.090 .909 & -2 \\
\hline April & 4.815 .909 .102 & 4.624 .999 .999 & 190.909 .103 & 0 & -190.909 .091 & 12 \\
\hline Mei & 5.714.090.924 & 5.714 .090 .915 & 9 & 0 & 0 & 9 \\
\hline Juni & 7.740 .568 .200 & 7.656 .363 .644 & 84.204 .556 & 0 & -84.204 .545 & 11 \\
\hline Juli & 10.498 .181 .835 & 10.419 .090 .924 & 79.090 .911 & 0 & -79.090 .909 & 2 \\
\hline Agustus & 11.780 .590 .926 & 11.206 .500 .022 & 574.090 .904 & 0 & -574.090 .907 & -3 \\
\hline September & 10.462 .545 .448 & 9.684 .363 .637 & 778.181 .811 & 0 & -778.181 .818 & -7 \\
\hline Oktober & 7.877.613.628 & 7.192.954.551 & 684.659 .077 & 0 & -684.659 .089 & -12 \\
\hline November & 6.486.249.996 & 6.061 .022 .731 & 425.227 .265 & 582.272 .727 & -1.007 .499 .998 & -6 \\
\hline Desember & 3.061 .545 .457 & 3.061 .545 .460 & -3 & 0 & 0 & -3 \\
\hline Total & 73.713.659.153 & 73.713.659.159 & -6 & 3.477.727.273 & -3.477 .727 .266 & 1 \\
\hline
\end{tabular}

Analisis

Penerapan Pajak

Pertambahan

Nilai pada PT

Sarana Aspal

Nusantara

296

Sumber : Data diolah

Dari hasil equaliasi antara penjualan versus DPP PPN menunjukkan bahwa terjadinya perbedaan antara penjualan dengan DPP PPN tersebut disebabkan karena adanya pembayaran-pembayaran dimuka (uang muka penjualan) dan adanya juga realisasi/ penyelesaian atas pembayaran dimuka tersebut.

Tabel 4

Rekapitulasi Pengkreditan PPN Masukan Periode Tahun 2016

(Dalam Rupiah)

\begin{tabular}{|c|c|c|c|c|c|}
\hline \multirow[t]{2}{*}{ Masa } & \multirow[t]{2}{*}{ Status SPT } & PPN Keluaran & PPN Masukan & $\begin{array}{c}\text { Kompensasi LB } \\
\text { Dari Masa } \\
\text { Sebelumnya } \\
\end{array}$ & $\mathrm{KB} /-\mathrm{LB}$ \\
\hline & & $\mathbf{a}$ & b & $\mathrm{C}$ & $e=a-(b+c)$ \\
\hline Januari & Normal & 17.400 .000 & 5.237 .223 & 0 & 12.162 .777 \\
\hline Februari & Normal & 14.909 .090 & 198.809 .841 & 0 & -183.900 .751 \\
\hline Maret & Normal & 164.181 .817 & 111.355 .435 & 183.900 .751 & -131.074 .369 \\
\hline April & Normal & 317.590 .910 & 317.105 .879 & 131.074 .369 & -130.589 .338 \\
\hline Mei & Normal & 1.513 .363 .635 & 680.113 .694 & 130.589 .338 & 702.660 .603 \\
\hline Mei & Pembetulan Ke-1 & 1.513 .363 .635 & 680.428 .828 & 130.589 .338 & 702.345 .469 \\
\hline Juni & Normal & 1.468 .716 .443 & 632.211 .527 & 315.134 & 836.189 .782 \\
\hline Juli & Normal & 720.659 .091 & 637.828 .101 & 0 & 82.830 .990 \\
\hline Agustus & Normal & 1.236 .390 .909 & 64.555 .085 & 0 & 1.171 .835 .824 \\
\hline Agustus & Pembetulan Ke-1 & 1.236 .390 .909 & 64.555 .085 & 0 & 1.171 .835 .824 \\
\hline September & Normal & 917.290 .901 & 568.272 .257 & 0 & 349.018 .644 \\
\hline September & Pembetulan Ke-1 & 917.290 .901 & 568.272 .257 & 0 & 349.018 .644 \\
\hline Oktober & Normal & 1.198 .345 .455 & 702.151 .358 & 0 & 496.194 .097 \\
\hline November & Normal & 1.438 .528 .863 & 872.832 .616 & 0 & 565.696 .247 \\
\hline Desember & Normal & 912.318 .171 & 460.465 .856 & 0 & 451.852 .315 \\
\hline
\end{tabular}

Sumber : Data diolah 
Analisis

Penerapan Pajak

Pertambahan

Nilai pada PT

Sarana Aspal

Nusantara

297
Sebelum pelaporan SPT Masa PPN dilakukan, perusahaan selalu melakukan perhitungan PPN melalui mekanisme pengkreditan Pajak Masukan, yaitu memperhitungkan Pajak Masukan dengan Pajak Keluaran sehingga dapat mengetahui dengan benar saldo nilai PPN pada suatu Masa Pajak. Apabila pada suatu masa pajak Pajak Masukan lebih besar dari pada Pajak Keluaran maka selisihnya merupakan kelebihan pajak yang dapat dimintakan kembali (restitusi) atau dikompensasikan ke masa pajak berikutnya. Sedangkan apabila pada suatu masa pajak Pajak Keluaran lebih besar dari pada Pajak Masukan maka selisihnya merupakan PPN yang harus disetorkan ke Kas Negara (lihat Tabel 4 dan Tabel $5)$.

Mekanisme Pengkreditan Pajak Masukan tersebut telah sesuai dengan ketentuan sebagaimana dimaksud pada Pasal 9 Undang-Undang No. 42 Tahun 2009 Tentang PPN dan PPnBM yaitu Pajak Masukan dalam suatu Masa Pajak dikreditkan dengan Pajak Keluaran dalam Masa Pajak yang sama, kemudian apabila dalam suatu Masa Pajak, Pajak Keluaran lebih besar daripada Pajak Masukan, selisihnya merupakan PPN yang harus disetor oleh PKP ke kas Negara dan apabila dalam suatu Masa Pajak, Pajak Masukan yang dapat dikreditkan jumlahnya lebih besar daripada Pajak Keluaran, selisihnya merupakan kelebihan pajak yang dikompensasikan ke Masa Pajak berikutnya.

Tabel 5

Rekapitulasi Pengkreditan Pajak Masukan Periode Tahun 2017

(Dalam Rupiah)

\begin{tabular}{|c|c|c|c|c|c|}
\hline \multirow[t]{2}{*}{ Masa } & \multirow[t]{2}{*}{ Status SPT } & PPN Keluaran & PPN Masukan & $\begin{array}{c}\text { Kompensasi LB } \\
\text { Dari Masa } \\
\text { Sebelumnya }\end{array}$ & KB/-LB \\
\hline & & $\mathbf{A}$ & B & $\mathbf{C}$ & $e=a-(b+c)$ \\
\hline Januari & Normal & 385.590 .908 & 914.734 .241 & 0 & -529.143 .333 \\
\hline Januari & Pembetulan Ke-1 & 385.590 .908 & 914.734 .241 & 0 & -529.143 .333 \\
\hline Februari & Normal & 140.999 .997 & 25.763 .398 & 529.143 .333 & -413.906 .734 \\
\hline Maret & Normal & 282.681 .819 & 16.993 .307 & 413.906 .734 & -148.218 .222 \\
\hline April & Normal & 462.500 .001 & 21.654 .264 & 148.218 .222 & 292.627 .515 \\
\hline Mei & Normal & 571.409 .085 & 191.045 .652 & 0 & 380.363 .433 \\
\hline Juni & Normal & 765.636 .356 & 850.923 .724 & 0 & -85.287 .368 \\
\hline Juli & Normal & 1.041 .909 .076 & 57.567 .409 & 85.287 .368 & 899.054 .299 \\
\hline Agustus & Normal & 1.120 .649 .978 & 1.058 .394 .682 & 0 & 62.255 .296 \\
\hline Agustus & Pembetulan Ke-1 & 1.120 .649 .978 & 1.041 .894 .682 & 0 & 78.755 .296 \\
\hline September & Normal & 968.436 .363 & 1.099 .668 .621 & 0 & -131.232 .258 \\
\hline Oktober & Normal & 719.295 .449 & 1.565 .117 .908 & 131.232 .258 & -977.054 .717 \\
\hline November & Normal & 606.102 .269 & 32.526 .813 & 977.054 .717 & -403.479 .261 \\
\hline Desember & Normal & 306.154 .540 & 31.650 .013 & 403.479 .261 & -128.974 .734 \\
\hline
\end{tabular}

Sumber : Data diolah

Pada SPT Masa PPN periode Tahun 2016-2017 terdapat beberapa pembetulan SPT Masa PPN, tindakan pembetulan tersebut pada umumnya dilakukan oleh Pengusaha Kena Pajak karena adanya beberapa faktor seperti adanya penggantian faktur pajak, pembatalan faktur pajak, dan lainnya. Secara perpajakan, pembetulan SPT PPN merupakan tindakan yang diperbolehkan hal ini sebagaimana mengacu pada ketentuan Pasal 8 Undang-Undang No. 28 Tahun 2007 Tentang Ketentuan Umum dan Tata Cara Perpajakan. Berkaitan dengan pembayaran PPN dan pelaporan SPT Masa PPN, perusahaan telah melakukan pembayaran PPN sesuai dengan ketentuan Pasal 2 dan Pasal 9 Peraturan Menteri Keuangan No. 242/PMK.03/2014 tentang Tata Cara Pembayaran dan Penyetoran PPN diantaranya yaitu 
PPN yang terutang dalam suatu Masa Pajak harus disetor paling lama akhir bulan berikutnya setelah Masa Pajak berakhir dan sebelum Surat Pemberitahuan (SPT) Masa PPN dilaporkan, dalam hal tanggal jatuh tempo pembayaran atau penyetoran pajak bertepatan dengan hari libur, pembayaran atau penyetoran pajak dapat dilakukan paling lambat pada hari kerja berikutnya. Dan sesuai dengan ketentuan Pasal 10 dan Pasal 12 Peraturan Menteri Keuangan No. 243/PMK.03/2014 tentang Tata Cara Pelaporan SPT Masa PPN yaitu Pemungut PPN wajib melaporkan PPN yang telah dipungut ke Kantor Pelayanan Pajak tempat Pemugut PPN terdaftar paling lama akhir bulan berikutnya setelah Masa Pajak berakhir, dalam hal batas akhir pelaporan bertepatan dengan hari libur, pelaporan dapat dilakukan paling lambat pada hari kerja berikutnya.

Tabel 6

Rekapitulasi Pembayaran dan Pelaporan PPN Periode Tahun 2016

\begin{tabular}{|l|l|l|c|c|}
\hline \multirow{2}{*}{ Masa } & \multicolumn{2}{|c|}{ SPT PPN } & \multicolumn{2}{c|}{ Tanggal } \\
\cline { 2 - 5 } Januari & \multicolumn{1}{|c|}{ Status } & \multicolumn{1}{c|}{ Saldo } & Bayar & Lapor \\
\hline Februari & Normal & Kurang Bayar & 23-Feb-16 & 26-Feb-16 \\
\hline Maret & Normal & Lebih Bayar & & 29-Mar-16 \\
\hline April & Normal & Lebih Bayar & & 28-Apr-16 \\
\hline Mei & Normal & Lebih Bayar & 24-Jun-16 & 30-Jun-16 \\
\hline Mei & Normal & Kurang Bayar & 24-Jun-16 & 29-Jul-16 \\
\hline Juni & Pembetulan Ke-1 & Kurang Bayar & 27-Jul-16 & 29-Jul-16 \\
\hline Juli & Normal & Kurang Bayar & 23-Agust-16 & 29-Agust-16 \\
\hline Agustus & Normal & Kurang Bayar & 21-Sep-16 & 27-Sep-16 \\
\hline Agustus & Normal & Kurang Bayar & 21-Sep-16 & 29-Nop-16 \\
\hline September & Pembetulan Ke-1 & Kurang Bayar & 25-Okt-16 & 28-Okt-16 \\
\hline September & Normal & Kurang Bayar & 25-Okt-16 & 29-Nop-16 \\
\hline Oktober & Pembetulan Ke-1 & Kurang Bayar & 22-Nop-16 & 29-Nop-16 \\
\hline November & Normal & Kurang Bayar & 23-Des-16 & 28-Des-16 \\
\hline Desember & Normal & Kurang Bayar & 23-Jan-17 & 27-Jan-17 \\
\hline
\end{tabular}

Sumber : Data diolah

Mengacu pada ketentuan Peraturan Menteri Keuangan No. 242/PMK.03/2014 tentang Tata Cara Pembayaran dan Penyetoran PPN dan Peraturan Menteri Keuangan No. No. 243/PMK.03/2014 tentang Tata Cara Pelaporan SPT Masa PPN maka berdasarkan data pada Tabel 6 dapat diketahui bahwa pada periode tahun 2016 perusahaan telah melakukan pembayaran PPN dan pelaporan SPT Masa PPN sesuai dengan ketentuan perpajakan yang berlaku sehingga dapat dikatakan bahwa pembayaran pajak dan pelaporan pajak pada periode tahun 2016 telah dilakukan dengan tepat waktu, meskpiun pada Masa Pajak Mei, Agustus dan September terdapat pembetulan SPT Masa PPN, namun pembetulan tersebut tidak mengakibatkan terjadinya keterlambatan baik secara pembayaran maupun pelaporan pajak.

Berbeda dengan yang terjadi pada periode tahun 2017, meskipun pada kondisi normal semua pembayaran PPN dan pelaporan SPT Masa PPN pada periode ini telah dilakukan dengan tepat waktu, namun dikarenakan adanya pembetulan SPT Masa PPN untuk Masa Pajak Agustus 2017 yang dilakukan pada Masa Pajak Maret 2018 yang menyebabkan saldo PPN Kurang Bayar bertambah menjadi lebih besar sehingga perusahaan baru melakukan pembayaran pelunasannya pada Masa Pajak Maret 2018 dan kondisi ini menyebabkan terjadi keterlambatan pembayaran PPN. Adapun pembetulan SPT
Penerapan Pajak

Analisis

Pertambahan

Nilai pada PT

Sarana Aspal

Nusantara

298 
Masa PPN tersebut dilakukan karena adanya adanya pembatalan faktur pajak masukan yang sebelumnya sudah dikreditkan.

Tabel 7

Rekapitulasi Pembayaran dan Pelaporan PPN Periode Tahun 2017

Analisis

Penerapan Pajak

Pertambahan

Nilai pada PT

Sarana Aspal

Nusantara

299
SPT PPN $\quad$ Tanggal

\begin{tabular}{|c|c|c|c|c|}
\hline \multirow{2}{*}{ Masa } & \multicolumn{2}{|c|}{ SPT PPN } & \multicolumn{2}{|c|}{ Tanggal } \\
\hline & Status & Saldo & Bayar & Lapor \\
\hline Januari & Normal & Lebih Bayar & & 29-Feb-17 \\
\hline Januari & Pembetulan Ke-1 & Lebih Bayar & & 30-Okt-17 \\
\hline Februari & Normal & Lebih Bayar & & 27-Mar-17 \\
\hline Maret & Normal & Lebih Bayar & & 26-Apr-17 \\
\hline April & Normal & Kurang Bayar & 23-Mei-17 & 29-Mei-17 \\
\hline Mei & Normal & Kurang Bayar & 15-Jun-17 & 19-Jun-17 \\
\hline Juni & Normal & Lebih Bayar & & 17-Jul-17 \\
\hline Juli & Normal & Kurang Bayar & 28-Agust-17 & 29-Agust-17 \\
\hline Agustus & Normal & Kurang Bayar & 22-Sep-17 & 29-Sep-17 \\
\hline Agustus & Pembetulan Ke-1 & Kurang Bayar & 09-Mar-18 & 16-Mar-18 \\
\hline September & Normal & Lebih Bayar & & 30-Okt-17 \\
\hline Oktober & Normal & Lebih Bayar & & 28-Nop-17 \\
\hline November & Normal & Lebih Bayar & & 18-Des-17 \\
\hline Desember & Normal & Lebih Bayar & & 29-Jan-18 \\
\hline
\end{tabular}

Sumber : Data diolah

\section{SIMPULAN DAN SARAN}

\section{Simpulan}

Berdasarkan hasil analisis yang telah dilakukan, maka dapat disimpulkan bahwa sebagai Pengusaha Kena Pajak, perusahaan telah melaksanakan hak dan kewajiban perpajakan Pajak Petambahan Nilai sesuai dengan ketentuan peraturan perpajakan yang berlaku. Diantaranya yaitu :

a. Melakukan pemungutan PPN dengan tarif $10 \%$ dengan menerbitkan Faktur Pajak pada saat melakukan transaski penjualan maupun pada saat menerima pembayaran Uang Muka Penjualan dari para pelanggannya.

b. Menghitung dan menentukan saldo PPN Kurang Bayar atau Lebih Bayar pada setiap Masa Pajak melalui mekanisme pengkreditan Pajak Masukan.

c. Melakukan pembayaran dan penyetoran PPN Kurang Bayar dengan benar.

d. Membuat dan melaporkan SPT Masa PPN dengan benar.

\section{Saran}

Adapun saran yang dapat diberikan adalah :

a. Pegawai yang menangani masalah perpajakan perusahaan hendaknya lebih teliti dalam proses pembuatan SPT Masa PPN dan juga harus aktif berkoordinasi dengan bagian terkait seperti Bagian Keuangan dan Bagian Akunting, hal ini sangat penting guna memperoleh data dan informasi dengan jelas mengenai hal-hal yang berkaitan dengan transaksi pembayaran, pembelian dan penjualan yang dapat digunakan dalam membuat perencanaan pajak sehingga dapat menghindari terjadinya Pembetulan SPT Masa PPN yang dapat berisiko menimbulkan sanksi administrasi pajak. 
b. Pegawai Bagian Pajak Perusahaan harus selalu mengupdate peraturan perpajakan agar dapat terhindar dari adanya kesalahan dalam mengurus masalah perpajakan perusahaan.

\section{DAFTAR PUSTAKA}

Republik Indonesia, Undang-undang Nomor 28 Tahun 2007 tentang Ketentuan Umum dan Tata Cara Perpajakan.

Republik Indonesia, Undang-undang Nomor 42 Tahun 2009 tentang Pajak Pertambahan Nilai Barang dan Jasa dan Pajak Penjualan atas Barang Mewah.

Mardiasmo. Perpajakan. Edisi Terbaru 2016. Yogyakarta, Andi, 2016.

Sukardji, Untung. Pajak Pertambahan Nilai. PPN. Edisi Revisi 2015. Jakarta, Rajawali Pers, 2015. Wardoyo., Subiyakto. Taxation. Pengantar Perpajakan Indonesia. Tangerang. TaxSys, 2017.

Darmansyah, Hafifa. 2013. Analisis Penerapan SPT Masa PPN Dan Hubungannya Terhadap Laporan Keuangan Pada PT. Duta Firza. Jurnal Lentera Akuntansi 1 (1). ISSN : 23392991.

Lalujan.2013. Analisis Penerapan Pajak Pertambahan Nilai Pada PT. Agung Utara Sakti Manado. Jurnal EMBA. Vol.1, No.3, 2013, Hal 140-149.

Januri.2017.Analisis Penerapan Akuntansi Pajak Pertambahan Nilai Pada PT. Perkebunan Analisis Penerapan Pajak Pertambahan Nilai pada PT Sarana Aspal Nusantara Nusantara IV Medan. Media Akuntansi Perpajakan. Vol.2, No. 2, 2017, 1-8. 